\title{
Identification and functional characterization of DR6, a novel death domain-containing TNF receptor
}

\author{
Guohua Pan ${ }^{\mathrm{a}, *}$, Johannes H. Bauer ${ }^{\mathrm{a}}$, Valsala Haridas ${ }^{\mathrm{c}}$, Shuxia Wang ${ }^{\mathrm{b}}$, Ding Liu ${ }^{\mathrm{b}}$, \\ Guoliang $\mathrm{Yu}^{\mathrm{b}}$, Claudius Vincenz ${ }^{\mathrm{a}}$, Bharat B. Aggarwal ${ }^{\mathrm{c}}$, Jian Ni ${ }^{1, \mathrm{~b}}$, Vishva M. Dixit ${ }^{2, \mathrm{a}}$ \\ ${ }^{a}$ Department of Pathology, University of Michigan Medical School, 1301 Catherine Road, Ann Arbor, MI 48109, USA \\ ${ }^{\mathrm{b}}$ Human Genome Sciences, Inc., 9410 Key West Avenue, Rockville, MD 20850-3338, USA \\ ${ }^{\mathrm{c}}$ Cytokine Research Section, Department of Molecular Oncology, University of Texas M.D. Anderson Cancer Center, Houston, TX 77030, USA
}

Received 2 June 1998

\begin{abstract}
Tumor nectosis factor (TNF) receptors are key players in inflammation and immune regulation. A new member of this family, termed death receptor-6 (DR6), has been identified. Like other death receptors, DR6 is a type I transmembrane receptor, possesses four extracellular cysteinerich motifs and a cytoplasmic death domain. DR6 is expressed in most human tissues and abundant transcript was detected in heart, brain, placenta, pancreas, thymus, lymph node and several non-lymphoid cancer cell lines. DR6 interacts with TRADD, which has previously been shown to associate with TNFR1. Furthermore, ectopic expression of DR6 in mammalian cells induces apoptosis and activation of both NF- $\mathrm{KB}$ and JNK.

(C) 1998 Federation of European Biochemical Societies.
\end{abstract}

Key words: Tumor necrosis factor receptor; Death receptor; Death domain; Nuclear factor $\kappa \mathrm{B}$; JNK

\section{Introduction}

Members of the tumor necrosis factor (TNF) receptor family are crucial modulators of inflammatory and cellular immune responses and mediate a variety of biological functions ranging from cell proliferation, differentiation and apoptosis to cell survival [1-7]. This family of receptors is characterized by several extracellular, cysteine-rich motifs that compose the ligand binding domain [2,5]. Upon ligation by their cognate ligands, these receptors engage a number of signal transduction pathways, including apoptosis, activation of NF- $\mathrm{KB}$ and JNK pathways that modulate the expression of genes involved in the immune and stress response [5].

Within the TNF receptor family, six members have emerged as a distinct subgroup termed death receptors; they contain a cytoplasmic death domain and activation of these receptors leads to engagement of components of the cell death pathway $[1,3]$. Transmission of the death signal is mediated by a series of homophilic protein-protein interactions involving the death domain and death effector domain that was originally defined as being present in the adaptor molecule FADD/MORT1 and the death protease caspase- 8 [8]. For example, when the death

\footnotetext{
*Corresponding author.

Present address: The Department of Endocrinology, Genentech, Inc., 1 DNA Way, M/S-37, South San Francisco, CA 94080, USA.

Fax: (1) (650) 225-6497. E-mail: jgpan@gene.com

${ }^{1}$ Shares a senior authorship.
}

${ }^{2}$ Present address: The Department of Molecular Oncology, Genentech, Inc., 1 DNA Way, M/S-40 South San Francisco, CA 94080, USA. receptor CD95/Fas is ligated by cognate ligand or agonist antibody, the adaptor molecule FADD and the death protease caspase- 8 are recruited to the signalling complex through interactions involving death and death effector domains, respectively [8-10]. On approximation, caspase-8 undergoes an autoactivation, initiating activation of the downstream caspases, cleavage of death substrates and demise of the cell [11-14]. In contrast to CD-95 that directly engages the FADD-caspase- 8 pathway $[9,10,15,16]$, both TNFR1 and death domain-3 (DR3) utilize a primary adaptor molecule termed TRADD, around which assembles the FADD-caspase- 8 pathway, an NF- $\mathrm{B}$ activating pathway involving the death domain-containing Ser/Thr kinase RIP and a JNK activating pathway that is mediated by the adaptor molecule TRAF2 [17-23]. Finally, there exists a subsidiary death pathway involving the death domain-containing adaptor RAIDD that binds to caspase- 2 and has been shown to be part of the TNFR1 receptor complex, although the exact physiologic relevance of this redundant pathway remains unclear [24,25].

Here, we report the identification and initial characterization of DR6, a new member of the TNF receptor family possessing a cytoplasmic death domain. DR6 induced apoptosis in mammalian cells and was capable of engaging the NF$\kappa \mathrm{B}$ and JNK pathways.

\section{Materials and methods}

\subsection{Expression constructs}

DR6(42-655) and DR6 delta(42-460) were cloned into pCMV1FLAG (IBI-Kodak) as in-frame fusions to a $\mathrm{NH}_{2}$-terminal preprotrypsin leader sequence and FLAG tag encoded by the vector. cDNAs were obtained by polymerase chain reaction using DNA oligo primers for DR6: 5'-GGAAGATCTGCCAGAACAGAAGGCCTCGAAT-3' and 5'-CCATCTTCCTGACCTGCTGTAGTCTAGAGCC-3' and for DR6 delta: 5'-GGAAGATCTGCCAGAACAGAAGGCCTCGAAT-3' and 5'-GCCGACCACGA GCGGGCCTAGTCTAGAGCC-3'. Constructs encoding DR4, FADD, CD95, DR3, TRADD, ICH1-pro, RAIDD and RIP have been described previously $[15,17-19,23,26]$.

\subsection{Apoptosis assay}

Cell death assays were performed as described $[15,26]$. Both HeLa and MCF7 cells were transfected using the lipofectAMINE procedure (Life Technologies, Inc.) according to the manufacturer's instructions.

\subsection{Co-immunoprecipitation assay}

In vivo interaction assays have been described elsewhere [15,26]. 293 cells were transfected by means of calcium phosphate precipitation.

2.4. $N F-\kappa B$ luciferase assay

NF- $\mathrm{KB}$ luciferase assays were done as described $[15,26]$.

2.5. JNK activation assay

293 cells were cultured in MEM containing 10\% FBS. Cells were 
plated in 6-well plates and transfected with DR6-expressing plasmid or vector alone at $60-70 \%$ confluence by the lipofectAMINE method according to the manufacturer's instructions. Forty hours post transfection, cell extracts were prepared in lysis buffer containing $20 \mathrm{mM}$ HEPES, pH 7.4, 2 mM EDTA, $250 \mathrm{mM} \mathrm{NaCl}, 0.1 \% \mathrm{NP}-40,2 \mu \mathrm{g} / \mathrm{ml}$ leupeptin, $2 \mu \mathrm{g} / \mathrm{ml}$ aprotinin, $1 \mathrm{mM}$ PMSF, $0.5 \mu \mathrm{g} / \mathrm{ml}$ benzamide, $1 \mathrm{mM}$ DTT and $1 \mathrm{mM}$ orthovanadate. The C-jun kinase assay was performed by a modified method as described [27]. Briefly, cell extracts $(70 \mu \mathrm{g})$ were subjected to immunoprecipitation with $0.03 \mu \mathrm{g}$ anti-JNK antibody for $30 \mathrm{~min}$ at $4^{\circ} \mathrm{C}$. Immunocomplexes were collected by incubation with protein A/G-Sepharose beads for $30 \mathrm{~min}$ at $4^{\circ} \mathrm{C}$. The beads were extensively washed with lysis buffer $(4 \times 400 \mu \mathrm{l})$ and kinase buffer $(2 \times 400 \mu \mathrm{l}: 20 \mathrm{mM}$ HEPES, pH 7.4, $1 \mathrm{mM}$ DTT, 25 $\mathrm{mM} \mathrm{NaCl}$ ) and the kinase reaction allowed to proceed for $15 \mathrm{~min}$ at $30^{\circ} \mathrm{C}$ with $2 \mu \mathrm{g}$ GST-Jun(1-79) in $20 \mu \mathrm{l}$ containing $20 \mathrm{mM}$ HEPES, $\mathrm{pH} 7.4,10 \mathrm{mM} \mathrm{MgCl} 2,1 \mathrm{mM}$ DTT and $10 \mu \mathrm{Ci}\left[\gamma^{32} \mathrm{P}\right]$ ATP. Reactions were stopped by the addition of $15 \mu \mathrm{l}$ SDS-sample buffer and resolved by SDS-polyacrylamide gel electrophoresis. GST-Jun(1-79) was visualized by staining with Coomassie blue and the dried gel visualized following Phosphorimager analysis (Molecular Dynamics; Sunnyvale, CA) and quantitation by ImageQuant Software (Molecular Dynamics). For the JNK activity assay shown in Fig. 4B, $3 \times 10^{6} 293$ cells were co-transfected with the indicated constructs $(6.4 \mu \mathrm{g})$ together with $2.4 \mu \mathrm{g}$ of a JNK-myc expression plasmid. After transfection (approximately $36 \mathrm{~h}$ ), cell extracts were prepared by lysis in NP40 buffer $(20 \mathrm{mM}$ Tris- $\mathrm{HCl}, \mathrm{pH} 8.0,137 \mathrm{mM} \mathrm{NaCl}, 10 \%$ glycerol, $2 \mathrm{mM}$ EDTA, $5 \mathrm{mM} \mathrm{Na} \mathrm{VO}_{4}, 0.5 \mathrm{mM}$ PMSF and $1 \%$ NP40) plus protease inhibitor cocktail (BMB). Immunoprecipitation of JNK-myc was done using monoclonal anti-myc antibody (10 $\mu \mathrm{g}$, Babco) and immunocomplexes precipitated with $20 \mu \mathrm{l}$ protein G-Sepharose $(50 \%$ slurry, Sigma). The kinase assay utilized $2 \mu \mathrm{g}$ GST-Jun(1-79) as substrate, $50 \mathrm{mM}$ ATP and $5 \mu \mathrm{Ci}\left[\gamma^{32} \mathrm{P}\right] \mathrm{ATP}$ in $30 \mu \mathrm{l}$ kinase buffer $(30$ $\mathrm{mM}$ HEPES, $\mathrm{pH}$ 7.4, $7 \mathrm{mM} \mathrm{MnCl}_{2}, 5 \mathrm{mM} \mathrm{MgCl}_{2}$ and $1 \mathrm{mM}$ DTT).

\section{Results and discussion}

\subsection{Identification and molecular cloning of a new member of the TNF receptor family}

To identify additional TNF receptor-related molecules, we searched an expressed sequence tag (EST) database using the protein sequence of the extracellular, cysteine-rich, ligand binding domain of TNFR2 [28,29]. Several human EST cDNA clones were initially identified. Analyses of these clones revealed one that contained an open reading frame encoding a protein of 655 amino acids (Fig. 1A). Database searches, protein sequence alignment, and comparative analyses indicated this molecule to be a novel cell surface receptor related to the TNF receptor family and possessing an intracellular death domain (Fig. 1C). Thus, this new molecule was named death receptor 6 , or DR6 (see below).

DR6 had a putative signal sequence (amino acids 1-41), with the mature form predicted to start at amino acid 42 (Gln) [30]. The extracellular portion (amino acids 67-211) contains four TNFR-like cysteine-rich motifs that are most related to those of osteoprotegerin (OPG) and TNFR2 with $36 \%$ and $42 \%$ amino acid identities, respectively (Fig. 1B; data not shown). A transmembrane domain (amino acids 351-370) is followed by a 285 amino acids long cytoplasmic portion of the molecule that contains a death domain related to those of all known death receptors (Fig. 1C), being most related to the death domain of TNFR1 $(27.2 \%)$ and least like that of DR5 (19.7\%). Curiously, unlike other death receptors that have death domains present in their $\mathrm{COOH}$-terminus, the death domain in DR6 was located adjacent to the transmembrane domain followed by a 150 amino acid tail. Interestingly, following the death domain was a putative leucine zipper sequence overlapping with a proline-rich region, reminiscent of a SH3 domain-binding motif (Fig. 1A) [31]. Their functional relevance remains to be discovered.

\subsection{DR6 $m R N A$ expression in human tissues and cancer cell lines}

A $4 \mathrm{~kb}$ DR6 transcript was found in most tissues (Fig. 1D). The transcript was abundant in heart, brain, placenta, pancreas, lymph node, thymus, and prostate. Lower levels were detected in lung, skeletal muscle, kidney, testis, uterus, small intestine, colon, spleen, bone marrow, and fetal liver. However, adult liver and peripheral blood leukocytes expressed little DR6 mRNA. Additionally, smaller transcripts of 3.1 and $2.4 \mathrm{~kb}$ were observed in the testis and fetal liver, respectively.

Among human cancer cell lines, abundant transcript levels were detected in several non-lymphoid tumor cells, including cervical carcinoma HeLa S3, colorectal adenocarcinoma SW480, lung carcinoma A549, and melanoma G361 cells. Significantly, little or no expression was observed in lines of hematopoietic origin (Fig. 2D).

\subsection{DR6 induces apoptosis in mammalian cells}

Since ectopic expression of death receptors can induce cell death in a ligand-independent manner $[15,16,19,20,26]$, we tested if DR6 could induce apoptosis upon overexpression. When HeLa S3 cervical carcinoma cells were transfected with a DR6-expressing construct, $43 \%$ of the transfected cells underwent morphological changes characteristic of apoptosis (Fig. 2A). As expected, deletion of the putative death domain (DR6 delta) abolished its killing activity. Significantly, DR6 was unable to induce cell death in human breast carcinoma MCF7 cells, although they were very sensitive to DR4 killing (Fig. 2A and not shown), suggesting that the cell death pathway engaged by DR6 may be distinct from that engaged by other death receptors. Alternatively, the apoptotic activity of DR6 may be modulated by other signaling pathways it activates (see below) or ligand binding may be required to unveil its full killing capacity. Further work will be needed to address this issue.

Fig. 1. Predicted amino acid sequence of DR6. A: The open reading frame for DR6 defines a type I transmembrane protein of 655 amino acids. The GenBank accession number for the sequence: AF068868. The mature protein is predicted to start at amino acid 42 (Gln, indicated by a black triangle). The putative signal peptide and transmembrane domain are single and double underlined, respectively. Six potential $N$ glycosylation sites are indicated by black dots. The cytoplasmic death domain is boxed. An intracellular region containing a potential leucinezipper motif overlapping with a proline rich sequence is underlined with a thick line. B: Sequence alignment of extracellular cysteine-rich domains. Alignment was done with Megalign (DNASTAR) software. Shading represents identical residues. C: Sequence comparison of death domains. Alignment was done and represented in the same way as in B. OPG, osteoprotegerin. D: Tissue distribution of DR6. Human adult tissue, immune tissue and cancer cell line Northern (RNA) blots (Clontech) were probed with DR6 cDNA according to the manufacturer's instructions. The blots were subsequently probed with $\beta$-actin cDNA (not shown). The smaller transcripts in testis and fetal liver are indicated by black arrows. Sk. mus., skeletal muscle; Sm. int., small intestine; PBLs, peripheral blood leukocytes; LN, lymph node; BM, bone marrow, FL, fetal liver; HL-60, promyelocytic leukemia; Hela S3, HeLa cell line; K562, chronic myelogenous leukemia; MOLT-4, lymphoblastic leukemia; Raji, Burkitt's lymphoma; SW480, colorectal adenocarcinoma; A549, lung carcinoma; G361, melanoma. 
A

1 MGTSPSSSTALASCSRIARRATATMIAGSLLLLGFLSTTTAQPEQKASNLIGTYRHVDRATGQVLTCDKC 70 PAGTYVSEHCTṆTSLRVCSSCPVGTFTRHENGIEKCHDCSQPCPWPMIEKLPCAALTDRECTCPPGMFQS 140 NATCAPHTVCPVGWGVRKKGTETEDVRCKQCARGTFSDVPSSVMKCKAYTDCLSQNLVVIKPGTKETDNV 210 CGTLPSFSSSTSPSPGTAIFPRPEHMETHEVPSSTYVPKGMṆSTESṆSSASVRPKVLSSIQEGTVPDṆTS 280 SARGKEDVNKTLPNLQVVNHQQGPHHRHILKLLPSMEATGGEKSSTPIKGPKRGHPRQNLHKHFDINEHL 350 PWMIVLFLLLVLVVIVVCSIRKSSRTLKKGPRQDPSAIVEKAGLKKSMTPTQNREKWIYYCNGHGIDILK 420 LVAAQVGSQWKDIYQFLCNASEREVAAFSNGYTADHERAYAALQHWTIRGPEASLAQLISALRQHRRNDV 490 VEKIRGLMEDTTOLETDKLALPMSPSPLSPSPIPSPNAKLENSALLTVEPSPQDKNKGFFVDESEPLLRC 560 DSTSSGSSALSRNGSFITKEKKDTVLRQVRLDPCDLQPIFDDMLHFLNPEELRVIEEIPQAEDKLDRLFE 630 IIGVKSQEASQTLLDSVYSHLPDLL 655

\section{B}

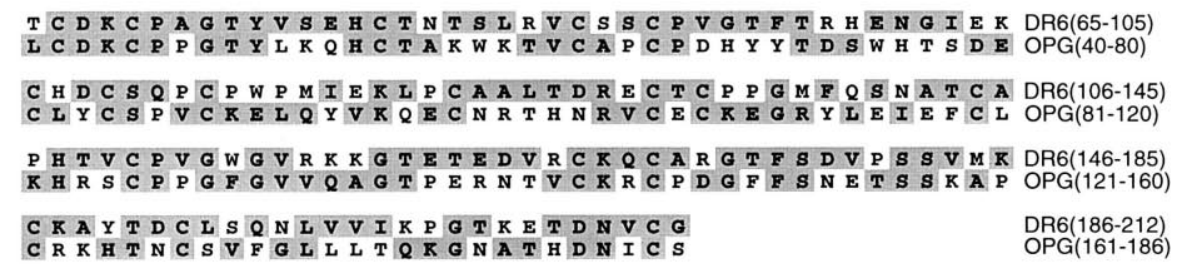

C

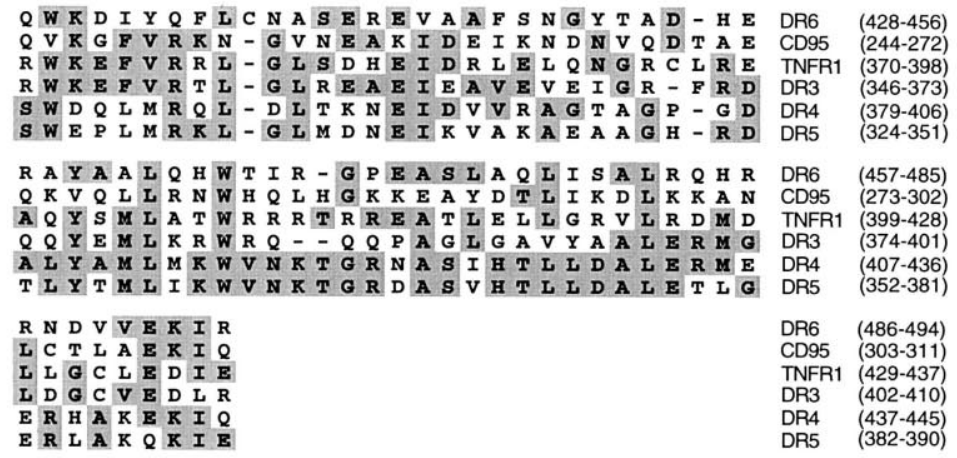

D

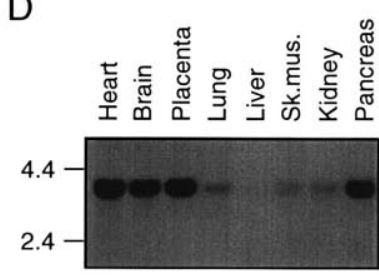

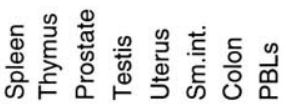

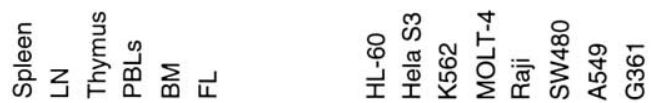

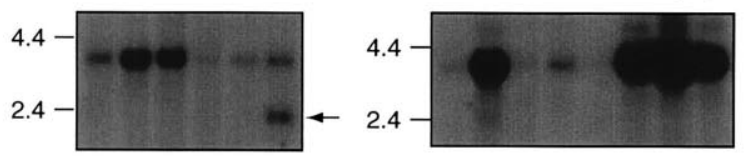




\section{A}

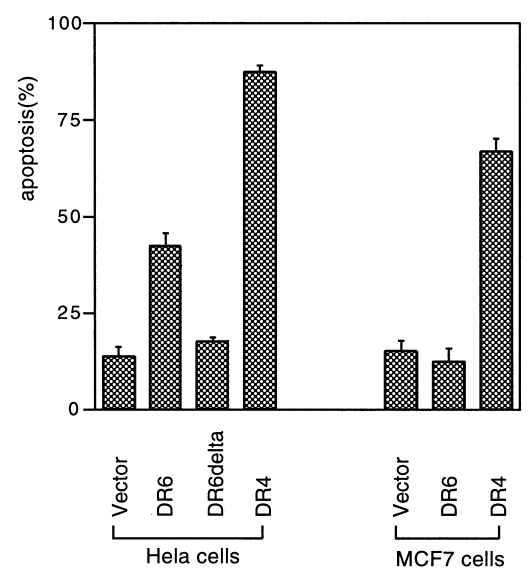

B
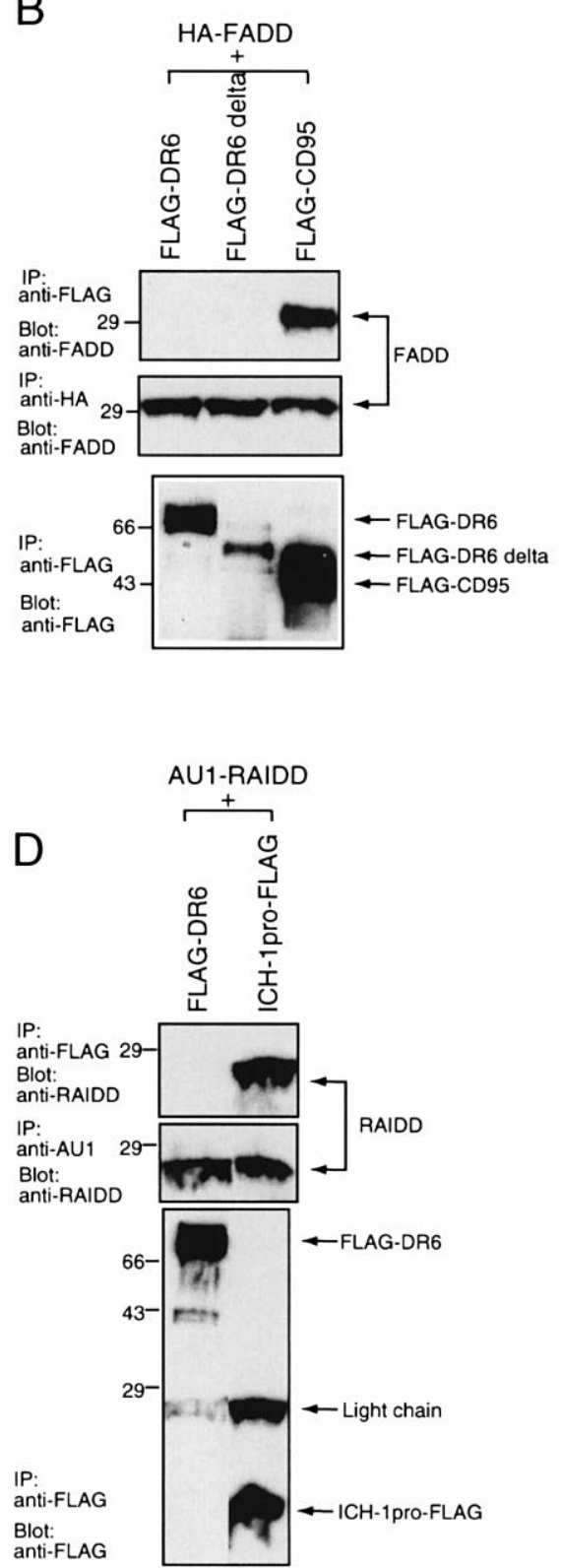

C

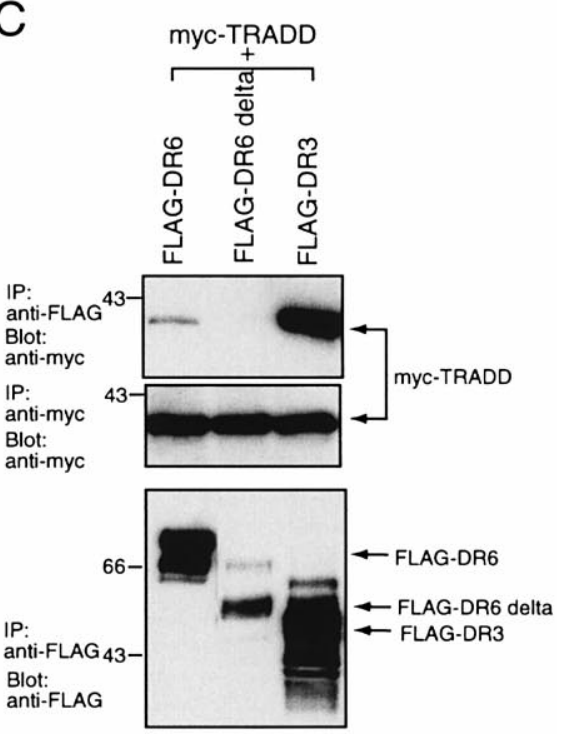

E

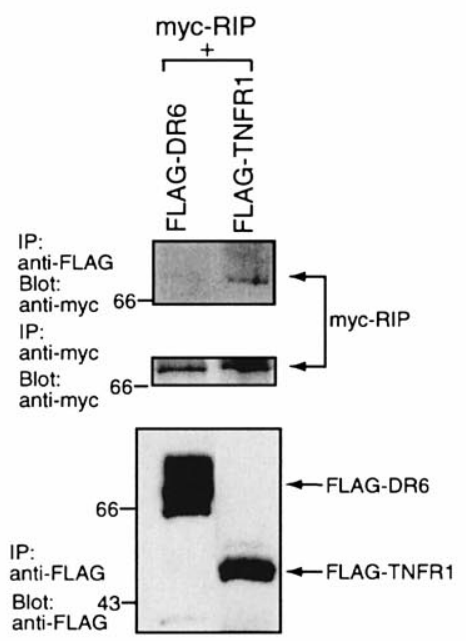


Fig. 2. DR6 induces apoptosis in mammalian cells. A: Ectopic expression of DR6 induces apoptosis in HeLa cells, but not in MCF7 cells. HeLa and MCF7 cells were cotransfected with an empty vector, DR6, DR6 delta or DR4 together with a $\beta$-galactosidase-expressing reporter construct using a lipofectamine method according to the manufacturer's instructions (BRL). Nineteen hours after transfection, cells were stained with 5-bromo-4-chloro-3-indoxyl- $\beta$-D-galactopyranoside $(\mathrm{X}-\mathrm{Gal})$ and examined [15]. The data (mean \pm S.D.) represent the percentage of round, apoptotic cells as a function of total $\beta$-galactosidase-positive cells $(n=4)$. B: Interaction of DR6 with adapter molecules. 293 cells were cotransfected with the indicated expression constructs using a calcium phosphate precipitation method. After transfection (at 38-40 h), cell lysates were prepared and the FLAG-tagged death receptors immunoprecipitated with FLAG M2 affinity gel (IBI-Kodak) and the presence of FADD, myc-tagged TRADD and RIP (myc-TRADD and myc-RIP), or RAIDD detected by immunoblotting with polyclonal antibody to FADD, horseradish peroxidase (HRP)-conjugated antibody to myc (BMB), or polyclonal antibody to RAIDD, respectively. Numbers to the left of the gels indicate molecular sizes in kilodaltons.

$\leftarrow$

\subsection{Interaction of DR6 with adaptor molecules in vivo}

Death receptors utilize the adaptor molecules FADD (for CD95) or both TRADD and FADD (for TNFR1 and DR3) to transmit the death signal $[15,16,19,20]$. We thus determined if DR6 could bind any of these adaptor molecules in human embryonic kidney 293 cells. DR6 did not interact with FADD, although the association between CD95 and FADD was readily detected under similar conditions (Fig. 2B). Interestingly, DR6 was found to associate with TRADD, although the interaction was weaker than that between DR3 and TRADD (Fig. 2C). This observation is consistent with the observation that DR6 has a weaker killing ability. Alternatively, DR6 may use a TRADD-related molecule as an adaptor, or the observed association might be bridged by another adaptor protein. Interaction was not detectable between DR6 and RAIDD or RIP, two other adaptor molecules known to be recruited to the TNFR1 and DR3 signalling complexes (Fig. 2D,E).

\subsection{DR6 activates $N F-\kappa B$}

Both TNFR1 and DR3 can engage a signal transduction pathway that leads to the activation of NF-KB $[5,19,20,28]$. The ability of DR6 to activate NF- $\mathrm{KB}$ was tested in a luciferase reporter assay and was found to induce NF- $\kappa B$ activation in a dose-dependent manner (Fig. 3, left). Presumably overexpressing the receptor allowed it to achieve an active configuration that was competent to signal the NF- $\mathrm{B}$ system. Interestingly, the cytoplasmic deletion of DR6 that abolished its

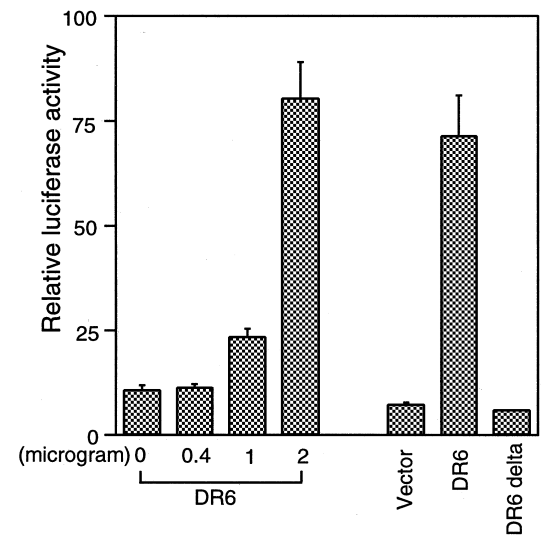

Fig. 3. DR6 mediates NF-KB activation. Cotransfection of 293 cells was performed with the indicated expression constructs and a NF$\mathrm{\kappa B}$ luciferase reporter construct. After transfection (at $36 \mathrm{~h}$ ), cell extracts were prepared and luciferase activities determined as described $[19,26]$. Transfection efficiency was monitored by $\beta$-galactosidase activity. A portion of the transfected cells was used to monitor expressioin of DR6 or DR6 delta (not shown). $2 \mu \mathrm{g}$ of each DNA construct was used for the luciferase assays shown on the left. apoptotic activity similarly abrogated its ability to activate NF- $\kappa \mathrm{B}$ (Fig. 3, right), suggesting that these two signaling pathways may be mediated by a common receptor-proximal adapter molecule.

\subsection{Ectopic expression of DR6 induces JNK activation}

JNK activation is known to be induced by several TNF receptors including TNFR1 and CD40 [5,21,22,28]. We next determined whether overexpression of DR6 could lead to JNK activation using an in vitro kinase assay. DR6 was found to induce JNK activation in a dose-dependent manner (Fig. 4A). The cytoplasmic truncation that attenuated cell death or NF- $\kappa \mathrm{B}$ activation had surprisingly little effect on JNK activation (Fig. 4B). This would be consistent with the notion that JNK activation is mediated by a cytoplasmic segment different from that responsible for apoptosis and NF- $\kappa \mathrm{B}$ induction. It is noteworthy that two potential TRAF-binding motifs are present adjacent to the transmembrane domain (PRQDP, amino acids 381-385 and PTQNR, amino acids

\section{A}
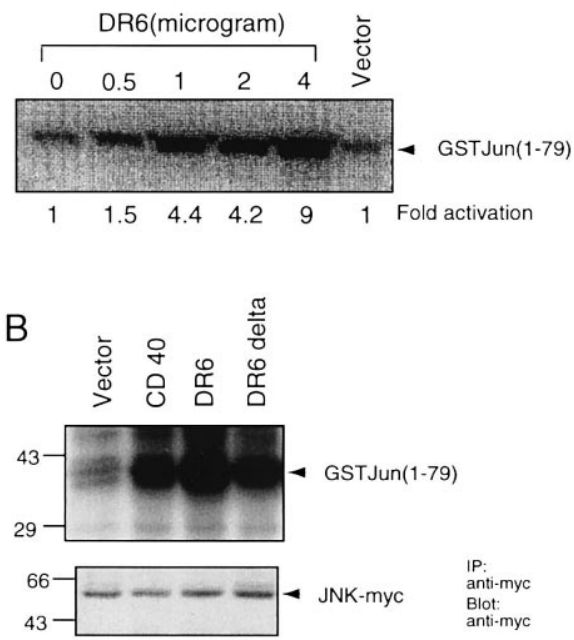

Fig. 4. DR6 induces JNK activation in mammalian cells. A: Transfections of 293 cells were done with the indicated amounts of DR6expressing plasmid or a vector control using the lipofectamine method. After transfection (at $40 \mathrm{~h}$ ), cell extracts were prepared and assayed for JNK activity as described in Section 2. B: Cotransfection of 293 cells was performed with the indicated constructs together with JNK-myc-expressing plasmid using the calcium phosphate precipitation method. Thirty-six hours post transfection, cell lysates were prepared and assayed for JNK activity as described in Section 2. JNK-myc was immunoprecipitated with anti-myc and detected by blotting with anti-myc-HRP (BMB, bottom panel). FLAG-tagged CD-40, DR6 and DR6 delta were immunoprecipitated with antiFLAG M2 affinity gel and detected by blotting with anti-FLAG antibody (not shown). 
400-404) [32-34]. Mutational analysis will be required to understand their functional significance.

In conclusion, we have identified a novel death domaincontaining TNF receptor designated DR6. DR6 engages a cell death pathway different from those initiated by the CD95, TNFR1 or TRAIL/Apo2L receptors. In addition, DR6 also activates NF-KB and JNK, two signaling pathways shared by TNFR1. Although its physiological function is unknown, it is probable that, like the other members of the TNF receptor family, DR6 may play a role in inflammatory responses and immune regulation. Identification of the ligand and targeted gene disruption will further our understanding of the physiologic role of this new member of the TNF receptor family.

Acknowledgements: A special thanks to K. O'Rourke for helping with the constructs and manuscript. We thank R. Davis for GST-Jun(1-79) construct, D. Goeddel for RIP and TRADD constructs, L. Holzman for JNK-myc expression constructs, T. Hlaing for preparing GSTJun(1-79) protein, other members of the Vincenz and Dixit laboratories for useful discussions and reagents, S. Pheley and I. Jones for assistance in preparing figures, and B. Schumann for secretarial assistance. G. Pan holds a Special Fellowship from the Leukemia Society of America. Supported by NIH Grants ES08111 and DAMD1796-6085.

\section{References}

[1] Nagata, S. (1997) Cell 88, 355-365.

[2] Armitage, R.J. (1994) Curr. Opin. Immunol. 6, 407-413.

[3] Golstein, P. (1997) Curr. Biol. 7, R750-R753.

[4] Baichwal, V.R. and Baeuerle, P.A. (1997) Curr. Biol. 7, R94 R96.

[5] Smith, C.A., Farrah, T. and Goodwin, R.G. (1994) Cell 76, 959962.

[6] Anderson, D.M., Maraskovsky, E., Billingsley, W.L., Dougall, W.C., Tometsko, M.E., Roux, E.R., Teepe, M.C., Dubose, R.F., Cosman, D. and Galibert, L. (1997) Nature 390, 175179.

[7] Cleveland, J.L. and Ihle, J.N. (1995) Cell 81, 479-482.

[8] Chinnaiyan, A.M. and Dixit, V.M. (1997) Semin. Immunol. 9, 66-67.

[9] Muzio, M., Chinnaiyan, A.M., Kischkel, F.C., O'Rourke, K., Shevchenko, A., Ni, J., Scaffidi, C., Bretz, J., Zhang, M., Gentz, R., Mann, M., Krammer, P.H., Peter, M.E. and Dixit, V.M. (1996) Cell 85, 817-827.
[10] Boldin, M.P., Goncharov, T.M., Goltsev, Y.V. and Wallach, D. (1996) Cell 85, 803-815.

[11] Muzio, M., Salvesen, G.S. and Dixit, V.M. (1997) J. Biol. Chem. 273, 2952-2956.

[12] Barinaga, M. (1998) Science 280, 32-34.

[13] Salvesen, G.S. and Dixit, V.M. (1997) Cell 91, 443-446.

[14] Martin, S.J. and Green, D.R. (1995) Cell 82, 349-352.

[15] Chinnaiyan, A.M., O'Rourke, K., Tewari, M. and Dixit, V. (1995) Cell 81, 505-512.

[16] Boldin, M.P., Varfolomeev, E.E., Pancer, Z., Mett, I.L., Camonis, J.H. and Wallach, D. (1995) J. Biol. Chem. 270, 7795.

[17] Hsu, H., Xiong, J. and Goeddel, D. (1995) Cell 81, 495-504.

[18] Hsu, H., Huang, J., Shu, H.-B., Baichwal, V. and Goeddel, D. (1996) Immunity 4, 387-396.

[19] Chinnaiyan, A.M., O’Rourke, K., Yu, G.-L., Lyons, R.H., Garg, M., Duan, R., Xing, L., Gentz, R., Ni, J. and Dixit, V.M. (1996) Science 274, 990-992.

[20] Kitson, J., Raven, T., Jiang, Y.-P., Goeddel, D., Giles, K.M., Pun, K.-T., Grinham, C.T., Brown, R. and Farrow, S.N. (1996) Nature 384, 372-375.

[21] Yeh, W.-C., Shahinian, A., Speiser, D., Kraunus, J., Billia, F., Wakeham, A., de la Pompa, J.L., Ferrick, D., Hum, B., Iscove, N., Ohashi, P., Rothe, M., Goeddel, D.V. and Mak, T.W. (1997) Immunity 7, 715-725.

[22] Lee, S.Y., Reichlin, A., Santana, A., Sokol, K.A., Nussenzweig, M.C. and Choi, Y. (1997) Immunity 7, 703-713.

[23] Kelliher, M.A., Grimm, S., Ishida, Y., Kuo, F., Stanger, B.Z. and Leder, P. (1998) Immunity 8, 297-303.

[24] Duan, H. and Dixit, V.M. (1997) Nature 385, 86-89.

[25] Ahmad, M., Srinivasula, S.M., Wang, L., Talanian, R.V., Litwack, G., Fernandes-Alnemri, T. and Alnemri, E.S. (1997) Cancer Res. 57, 615-619.

[26] Pan, G., O'Rourke, K., Chinnaiyan, A.M., Gentz, R., Ebner, R., Ni, J. and Dixit, V.M. (1997) Science 276, 111-113.

[27] Haridas, V., Darnay, B.G., Natarajan, K., Heller, R. and Aggarwal, B.B. (1998) J. Immunol. 160, 3152-3162.

[28] Baker, S.J. and Reddy, E.P. (1996) Oncogene 12, 1-9.

[29] Tartaglia, L.A. and Goeddel, D.V. (1992) Immunol. Today 13, 151-153.

[30] Nielson, H., Engelbrecht, J., Brunak, S. and Heijne, G.V. (1997) Protein Eng. 10, 1-6.

[31] Pawson, T. and Scott, J.D. (1997) Science 278, 2075-2080.

[32] Gedrich, R.W., Gilfillan, M.C., Duckett, C.S., Van Dongen, J.L. and Thompson, C.B. (1996) J. Biol. Chem. 271, 12852-12858.

[33] Devergne, O., Hatzivassiliou, E., Izumi, K.M., Kaye, K.M., Kleijnen, M.F., Kieff, E. and Mosialos, G. (1996) Mol. Cell. Biol. 16, 7098-7108.

[34] Boucher, L.-M., Marengere, L.E.M., Lu, Y., Thukral, S. and Mak, T.W. (1997) Biochem. Biophys. Res. Commun. 233, 592600. 